\title{
Identification of Public Green Open Space in The Merdeka Square Area of Binjai City: Social Reality Architecture
}

\author{
Deni*, Wanda Heria Lestari, Erna Muliana, Nasruddin \\ Department of Architectural Engineering, Universitas Malikussaleh, Aceh, Indonesia \\ *Corresponding authorE-mail:deni@unimal.ac.id
}

Manuscript received 16 Nov 2021; revised 20 Nov 2021; accepted 1 Jan 2022. Date of publication 10 Jan 2022

\begin{abstract}
Urban Green Open Space has important benefits for the lives of its residents. However, the problem that often arises is that there are many green open spaces in the city only as spaces that are responsive to the climate, environment, and as noise absorbers. Even though its existence is more than that, Green Open Space should also be able to fulfill the social activities of city dwellers in interacting, communicating and other social realities to create positive mental growth for fellow city residents. Architecture can be used as a vehicle to make a place not only a visual use but also can be a benefit for human life in the quality of its social reality. Therefore, research activities are needed by observing the relationship between Green Open Space and social activities of the city community as users to find the identity of the place so that the character is seen as the cause of the place to exist. The research was conducted by adopting a qualitative method that was translated descriptively at certain times in a factual manner so that the audience got a clear picture of the social reality that occurred. The results of the study explain that the pattern of activities that occur interactively on the character of the place provided contextually is intended for teenage visitors. There is no strict place limit between adolescent habitus social activities, this is a stereotype of the arena, capital, and power of adolescents who tend to be free.
\end{abstract}

Keywords: Green Open Space (RTH), Spatial Activity, Social Reality.

\section{Introduction}

Urban green open space has very important life benefits in terms of balancing the temperature of the city space and in terms of service activities for its residents. Apart from being the lungs of the city, Green Open Space is also useful as a place to produce oxygen, as a pollution filter, a shaded area to reduce noise pollution. According to the Directorate General of Spatial Planning, Ministry of Public Works, to obtain the functional and aesthetic qualities of green open space in an urban system, the minimum area, pattern, and structure, as well as its form and distribution are certain aspects of consideration in building and developing it. Ecological character, conditions of the desire of city residents, as well as the direction of development goals and urban development are the main determinants in determining the functional content of green open space [1].

The minimum amount of Green Open Space based on Law Number 6 of 2007, concerning Spatial Planning is 30\% of the city's area. The proportion of green open space in urban areas is at least $30 \%$ consisting of $20 \%$ public green open space and $10 \%$ consisting of private green open space. The ideal public green open space is $30 \%$ of the total area, apart from being an environmental facility, it can also function for the protection of certain habitats, as agricultural cultivation, improving the quality of the atmosphere, supporting water and soil conservation. The preservation and expansion of green open space can be formulated as health benefits for every individual that can provide reasons for environmentally friendly policy decisions. The more urban communities use public green open space optimally and positively, the more positive quality is seen in meeting the needs of urban community activities [2].

According to data from the Ministry of Public Works and Public Housing (PUPR), to date, only 13 out of 174 cities in Indonesia have participated in the Green City program and have a Green Open Space (RTH) portion of 30\% or more. Several factors as the cause of minimal use of green open space in big cities are caused by the limited land owned by the local government for the development and expansion of green open space, besides that the government also has limited funding due to the high price of strategic land in the city. Due to these conditions, the community can use public space with limited space capacity as well. This also affects the orientation of the community's limited social activities as well as a forum for social activities to gather [3].

The Binjai City Environmental Service (DLH) stated that currently, the ratio of public green open spaces in Binjai City reaches $9 \%$ of the total area of Binjai City covering $90.24 \mathrm{~km}^{2}$. The area of the green open space is not sufficient to meet the social activities of city dwellers and is still far from the ideal ratio set. The existence of Green Open Space in Binjai City provides benefits for the local community as a 
space to express creativity both socially and culturally which will have a positive effect on the personality of a person [4, p. 58] and a particular community [5].

Practically, Merdeka Square in Binjai City is one of the public spaces and is one of the objects of the visit by the local community, both on weekday nights and weekend nights. The place is not only used to maintain the quality of the city's atmosphere but also as a social space for the community to carry out local tourism activities every day. Some of the existing facilities are very helpful in the ongoing social practice. City dwellers and green space are two aspects of communication that support each other as a substance of good quality for the city's atmosphere and the lives of its residents. The activities of city dwellers in green open spaces that are harmonious, healthy, and sustainable have shown that green open space is not only an environment that can balance the quality of the city environment, but also greatly affects the mental health of residents in the scope of social activities in it. Therefore, research is needed on the attractiveness of the local community as a symbol of identity [6] comes from the pattern of social activities of the residents of Binjai City as a domain of identification of the green open space in the city of Binjai for a certain principle or reference approach as an instrument for recommending the provision of green open space as a space to balance the face of the city that has no direction for the cause of its existence [7].

\section{Literature Review}

Some of the previous literature related to the accessibility of the activity patterns of space actors towards public open spaces [8] and patterns of social activity in the use of public spaces [9]. Previous research was used as a reference and as additional material for writing. This is a phenomenon entity that Emmanuel Kant calls an aposteriori, which is a perception of experience that functions as the 'content' (material) of knowledge, which consists of object phenomena because ratios are active in compiling phenomena into knowledge according to ratio categories, so human knowledge does not maybe reach the noumenal [10].

According to Shevky dan Bell [11], the term pattern activity is an entity defined through its characteristics (features). A pattern is something that has a unique existence and is different from others, it can be interpreted through its characteristics. This explains everything that is done or from one action to another (between actions) that occurs both physically and non-physically, which is a scope of activity [12]. Social activity is a patterned arrangement related to a particular public space. The existence of these activities is marked by the movement of people in one place or moving to another place following the orientation of the activities to be carried out on existing facilities. Patterns of activity related to the environment and humans. Activities carried out by a person or group of people in an environment can be known at a certain time or situation, also cannot be separated from the area and space of activity [13].

Activity patterns and patterns of space utilization can be identified by observing their activities and movements. A good space will create new visitors and create a variety of activities and a place declared successful in creating visitor attraction. The orientation of visitors to spatial activities becomes a benchmark for the characteristics of a place as in the idea of Genius Loci [14] referred to as life-world, namely the human world in an abstract manner which refers to local relations consisting of parts of the identity contained in the phenomenon. By understanding how human interaction with place can be used as an approach in formulating design principles to produce an ideal space. The identity referred to in this case is spirit [14] created in a place that brings us to exist in understanding green open space in a relevant way.

However, simply collecting various activities that occur is not enough to get to green open space following the purpose of its existence both for the physical urban environment and the activities of non-physical city dwellers. To bring this closer, Pierre Bourdieu's thoughts on habitus [15] will be adapted to see the social identity of the green open space of Binjai City. This thinking explains the social reality of the community involved in social practices formed by the experience of certain activities originating from the arena, capital and power [16]. With the use of genius loci thinking by Norberg-Schulz combined with habitus thinking by Bourdieu, it is hoped that it will be closer to the clarity of research on the character of the findings into a certain typology as an image of urban social reality.

\subsection{Green Open Space (RTH) and The Unique Character of the Region}

Open space is equipped with roads, parking lots, pedestrian walkways, and trash cans to meet the needs of the community [17, p. 19]. Public open space is one type of space where people freely interact as a forum for community social activities [18]. A Green open space is a place that encourages people to carry out activities, both individually and in group [19]. Green Open Space at a certain time can be used as an orientation by the community as a destination that can represent their wishes like a green area as recreation activity in urban space [20, p. 297]. Visiting individuals, friends, family, or certain communities in maintaining social relations in the practice of activities both adapting to existing facilities formally and informally.

According to the regulation of the Government Republic of Indonesia No.26 of 2007 concerning the National Spatial Planning, article 1 paragraph 25 several aspects that must be considered in the management of green open space [21], namely:

1. Physically, green open space as the existence of the environment is a physical form with geographical limitations.

2. Social, green open space is a space that functions so that humans can socialize with their environment and surroundings.

3. Economy, green open space is a commercial area that can create profits for traders, parking attendants, and others.

4. Culture, a space to describe the arts and culture of the local community.

5. The need for the service of the rights of the population to obtain a comfortable, safe, beautifull and sustainable environment.

RTH Binjai City is geographically located right in the middle of the city which has easy access from all directions of city circulation. In addition to its location in the center of the city's administrative building environment, this location has an atmosphere of tranquility and togetherness for all circles of society as the right place to visit and meet in social reality. The area of RTH Binjai City is 1.5 hectares side by side with the Tugu Perjuangan 1945 monument as a sign of the city of fighters from the Dutch colonial colony. Binjai, which is part of the province of North Sumatra, was once used by the Netherlands as a spice exporting port in 1822 [22]. So Binjai City can be described as an Administrative city to support its regional status as an exporter of several crops at that time. The traces of urban spatial planning as an administrative city during the Dutch colonial period are still quite clear, one of the remains of the spatial planning can be seen in the Binjai Merdeka Square and its surroundings, which is the object of this research.

The characteristics of the research area as a Green Open Space are still preserved to this day:

1. The location is right in the city center.

2. It has good visuals because it is surrounded by government and private office buildings.

3. Easily accessible to residents inside and outside the city.

4. Has the physical condition of the arrangement of green open space that is still natural.

5. The most prominent area among other city elements. 
Some of the characteristics stated above explain the unique visual value based on history and other supporting visuals around the city. This condition has invited the community to carry out social and economic realities as the right place to get out of their routine activities, both individually and in groups. A 'place' is what is given, to the content as its existence [14]. Green open space is a qualitative form, a total phenomenon that cannot be reduced based on its physical condition alone, but by involving the spatial relationships contained in it [14]. Therefore, the physical aspect of RTH research covers the Binjai Merdeka Square as a whole (physical complex) and is completely composed of various elements that make up the place.

\subsection{Green Space Public Space in Social Reality}

Carr (1992) explains that public space is a shared space that is very easy to be accessed by the whole community for individual and group activities [18]. Open space is owned by individuals that can be accessed, entered, and used by everyone freely without exception.

Public space according to Rob Krier [23, p. 4] has two forms, namely:

1. Elongated (The street)

That is a space that is elongated and straight and has a tendency form to linear circulation pattern, one-way or parallel.

Example: Rivers, Roads, corridors, and others.

2. Square (The Square)

That is, a space that has almost the same dimensions on all sides, in the form of a circulation pattern in all directions, random, and organic

Example: Field, park, and others.

The shape of the RTH Merdeka Square in Binjai can be said to be square. In the form of green open space, it can also be translated that Binjai Merdeka Square is not a place with limited access for the community, on the contrary, that the place can be used by anyone, both residents who are in the city, and residents outside the city of Binjai. There is sufficient vegetation capacity to form the boundaries of green open space, there are also some sports equipment and a simple children's playground that can be used by the people who visit it. These facilities can be used as a basic instrument for the formation of social reality over the arena, capital, and power that are created individually and then propagate into groups and continue to the scale of other social relations.

Habitus is determined by the intellectual value of an individual or group in his social reality, it is the intellectual who will determine him as an actor who is following his arena, capital, and power [15]. People trade in goods and services, for example, the arena they have nonphysically is limited by the interests of buyers, traders as actors have the reality of power and are only limited to trading or selling goods and services in that place. While social capital [24] traders are formed depending on the type of goods or services sold to certain circles. For example, satay traders, the arena that he can reach is only adult buyers in his social reality, because the food is not for children's consumption. While the reality of his power is to process ready-to-eat food for buyers. While the reality of social capital is to determine the market segment for satay that is sold to immigrant communities. Aspects of the arena, capital, and power of satay traders are determined by the extent of their intellectual value in the existence of their social reality. The existence of this social reality can be stated as habitus practice because it has become a patterned or repeated satay activity are traders in the area for a long time.

In this study, habitus thinking does not translate all actors who use or operate in the research area in depth one by one but certain events collects it a whole as on to draw authentic conclusions about how the community treats.

\section{Methods}

This research uses a descriptive method [25] qualitative research to obtain an overview of case studies based on visible facts. The observations made focused on the combination of the practice of social reality with the form of space that was present at the Merdeka Square in the city of Binjai. Refers to one of the essences of descriptive qualitative research (Celeste Lawson, 2016, p. 156) the position of the researcher as an observer in this activity on the practice process of the social reality of the people who are living in the use of place. The first step was to map the boundaries of the research area, namely the Merdeka Square in Binjai City. After that, referencing the elements of space that are used as places by visitors as a forum for the process of practicing social activities are then filtered in mapping the characteristics of the place. Then the collective act of dominating social practices on certain elements of space is practically a direction that makes it easier to find the characteristics of green open space at the Merdeka Square of Binjai City.

While the research variables cover the physical conditions of the place that support the social, economic, and cultural aspects of the local community towards the practice process of their social reality, which is covered in the arena, capital, and power in a practical habitus. Practical habitus is meant in this case that observations are made at formal and informal times that represent the existence of social activities; informal time is the time when the community has an interest in visiting in the afternoon and evening, the location of the object of research at the formal time is where the community visits while undergoing academic and work routines. Finally, the object of research observation is physical (fixed) namely the image of the place in the form of facilities contained in the research area, and non-physical (not permanent), namely the activities of the visitor community in treating the area to fulfill their orientation and desires. In facilitating the visual track record of social activities, photo documentation and a map of the location of the research area are used as a guide for point conditions of the place.

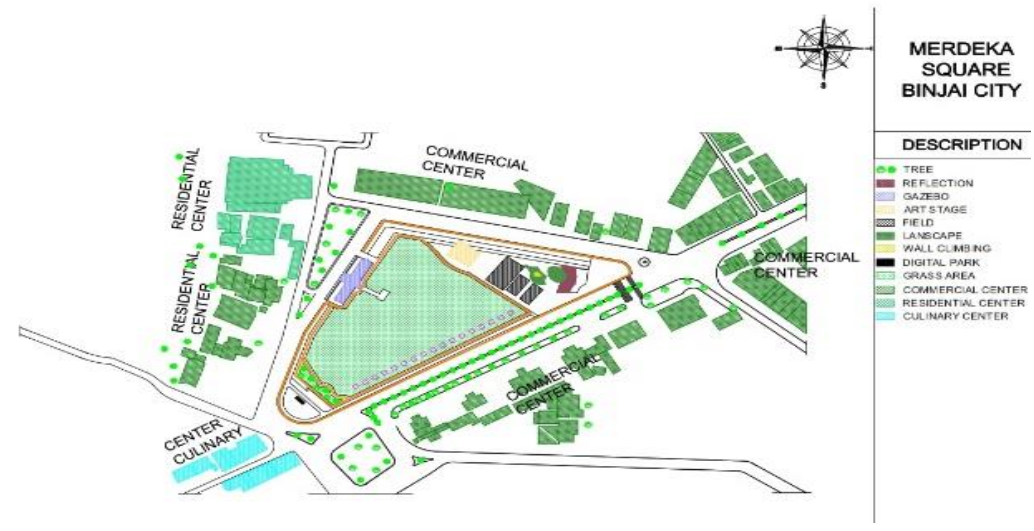

Fig 1. Research site situation map 


\section{Results and Discussion}

The types of activities that are referenced in observing activity patterns are classified based on the level of involvement in the use of public space, namely active engagement such as playing, sports, walking, selling, and passive engagement such as sitting and standing. While the physical conditions include the identification of places, forms, potentials, and public facilities.

\subsection{Physical Condition of the Independent Field Area}

Merdeka Square is open to the public and can be accessed at any time. The area has adequate facilities with various types of activities. Figure 2 shows the mapping of the situation and the existing description of Merdeka Square which is located between Jalan Veteran and Jalan Jendral Sudirman. The physical visual of the area is that there is an expanse of grass that extends in the middle, bordered by a paved path and covered with an arrangement of vegetation throughout the outermost boundary of the area. Then there are certain places whose existence is located between the pavement and grass as supporting elements of green open space.

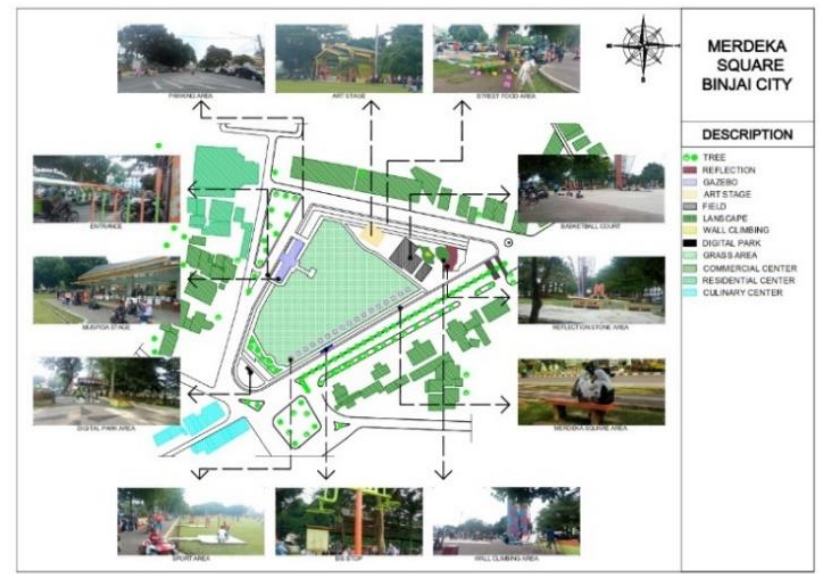

Fig 2. Mapping Existing Merdeka Square Area

\subsubsection{Identification of the Form and Circulation of Merdeka Square}

The square shape of the area is easy to access for visits from all sides, this shows the circulation of social activity practices that are not limited to places. In addition to the area having no time limit for visits, the community as an actor providing goods and services can easily by personally determine the regional spaces that he can make a place for work activities as a carrying capacity for visitors in the practice of social activities.

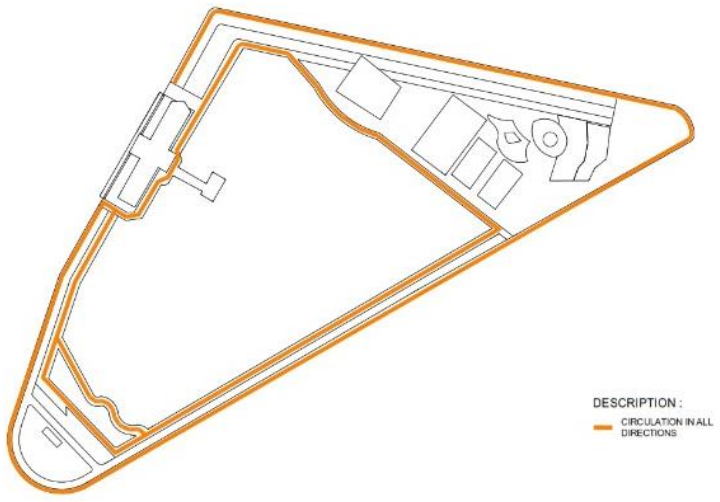

Fig 3. Merdeka Square Random Circulation

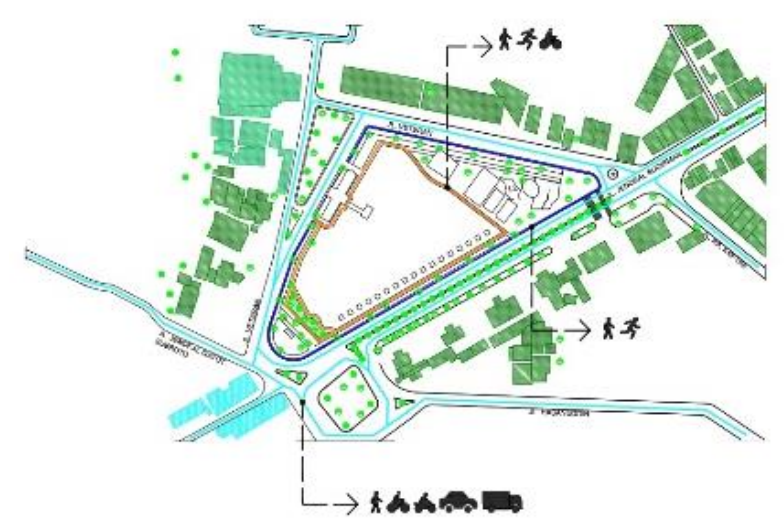

Fig 4. Merdeka Square Street Class Circulation

In Figure 4 the road classes are marked by differentiating the colors between circulations. Tosca color as a marker of highway circulation which is the busiest road that connects to the area has a road body width of 11 meters so that it can be traversed by various vehicles ranging from pedestrians, motorcycles, cars, and other vehicles. The blue color indicates the pedestrian circulation of the sidewalk and the orange color as the pedestrian circulation as well as the jogging track area.

\subsubsection{Identification of Potential Social Activities}

The potential that stands out as an act of identification in the reference area is as follows: 
Table 1. Identification of Binjai City Merdeka Square

Potential Identification Based on

Physical form

Natural Condition

Location and accessibility

Visitor activities

\section{The potential that arises}

The area is the largest public green open space in Binjai City, anyone can visit both on weekdays and weekends. Merdeka field is used by local people and outside the city as local tourism for recreational areas, both individually and in groups.

The natural conditions of the area are following the situation of the tropics, having a longer summer period will affect the time of activity in the grass area, making it impossible for activities to be carried out all the time.

The area is located in the city center and is very easily accessible to the local community as well as people outside the city of Binjai.

Visitors who come for recreation and activities are following the physical orientation of the area as a green open space and as certain activities that come from available facilities. The highest visits are in the afternoon until the evening. The presence of street vendors (PKL) seems to support visitors who come to enjoy snacks and other necessities that are sold.

The table above explains that the potential of a place can easily create social reality practices based on the orientation of visitors. The physical form of the area that supports gathering with the protection of trees for social interaction, the boundaries of places that make it easier for visitors to map and share social activities with other visitors, and the movement of the visitor community as a whole can be carefully observed without any clear boundaries. strengthen green open space as a center of social activity in this city.

\subsubsection{Regional Carrying Capacity to Social Reality}

The existence of supporting facilities is the pattern of social activities in the area. In table 2 can be seen that the completeness of some of the facilities offered is quite diverse and attracts the attention of visitors. The existing facilities have a very important aspect to the capacity of the number of visits, the more facilities there are, the more visitors will also increase because these supporting facilities can represent the orientation and desires of visitors.

Table 2. Distribution of Merdeka Square Area Facilities

\begin{tabular}{|c|c|c|}
\hline Facility & Equipment & Description \\
\hline $\begin{array}{l}\text { Main } \\
\text { Facilities }\end{array}$ & $\begin{array}{l}\text { Green open space } \\
\quad \text { (grass area) }\end{array}$ & $\begin{array}{l}\text { The available open space is used as seating, sports areas such as running, soccer, } \\
\text { gymnastics and pencak silat training. }\end{array}$ \\
\hline \multirow{12}{*}{$\begin{array}{l}\text { Supporting } \\
\text { Facilities }\end{array}$} & MUSPida Performance & $\begin{array}{l}\text { Formal MUSPIDA performances are often used for regional government deliber- } \\
\text { ations, flag ceremony areas and other regional events. Informally as a skateboard } \\
\text { practice area for beginners, sit, eat and drink together. }\end{array}$ \\
\hline & Performing art Festival & $\begin{array}{l}\text { Art stage is formally used as a place used by the community for art studios and } \\
\text { music concert events. Meanwhile, informally, this place is used by visitors as a } \\
\text { gathering place. }\end{array}$ \\
\hline & Merdeka Square Park & The park is often used by visitors as a place for selfie objects. \\
\hline & Reflection Stone Area & $\begin{array}{l}\text { An area for the elderly visitor community to carry out health therapy by crossing } \\
\text { the area by communicating and interacting with each other. }\end{array}$ \\
\hline & Rock Climbing Rides & $\begin{array}{l}\text { Rock climbing rides are used as a place to test courage and dexterity even though } \\
\text { at this time the demand is decreasing. }\end{array}$ \\
\hline & Basketball Court & As a place for basketball. \\
\hline & Volleyball Field & As a place for volleyball. \\
\hline & Badminton Sports Field & As a badminton sport venue. \\
\hline & $\begin{array}{l}\text { Outdoor Sports Equipment } \\
\text { Area }\end{array}$ & As a place to warm up or workout. \\
\hline & $\begin{array}{l}\text { Digital Park } \\
\text { (wi-fi corner) }\end{array}$ & As an educational area and dive into the virtual world to interact virtually. \\
\hline & Parking area & $\begin{array}{l}\text { The vehicle parking area is located around the road that surrounds the area, this } \\
\text { place is a personal act carried out by visitors because there is no explicit placement } \\
\text { of this space. }\end{array}$ \\
\hline & Street vendors area & $\begin{array}{l}\text { The area does not provide an area for street vendors, but they can use the road to } \\
\text { carry out their work activities. }\end{array}$ \\
\hline $\begin{array}{l}\text { Supporting } \\
\text { Facilities }\end{array}$ & Accessibility & $\begin{array}{l}\text { The accessibility of the area has a very strategic location because it is in the heart } \\
\text { of the city of Binjai. }\end{array}$ \\
\hline
\end{tabular}


Accessibility is available not only outside the area but also inside the area. Various facilities such as rock climbing, reflection, basketball court, and other facilities have clear access to achievements, making it easier for visitors to do activities according to their orientation. Various supporting facilities can be seen in the mapping below:

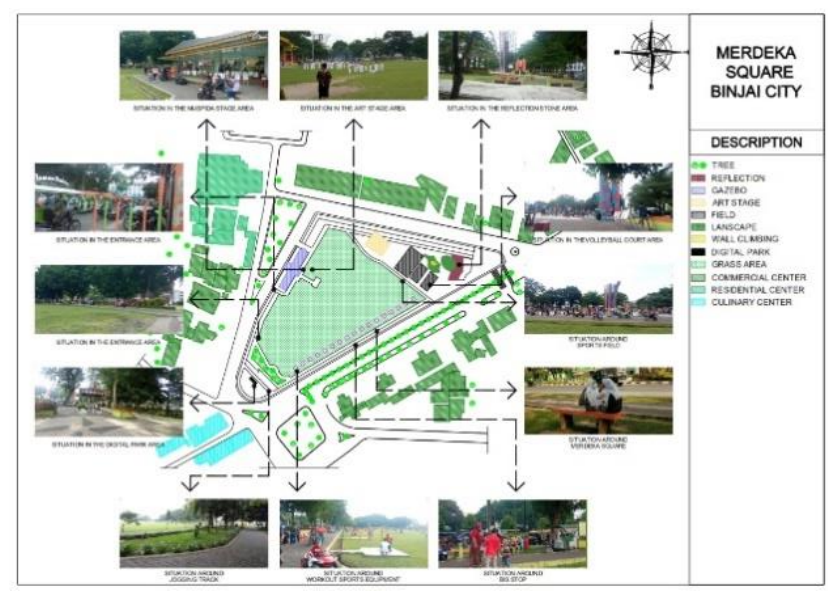

Fig 5. Mapping Supporting Facilities

To facilitate maintenance and the physical condition of the area to stay awake for along times, there is adequate artificial lighting for night use, trash cans, hydrants, permanent park benches, and several other service facilities. The existence of these service facilities (figure 6) makes it easier for the community to use the main facilities and available supporting facilities. With these service facilities, there is a hidden firmness for visitors to always participate in maintaining the physical existence of the area so that it is always maintained for the common good.

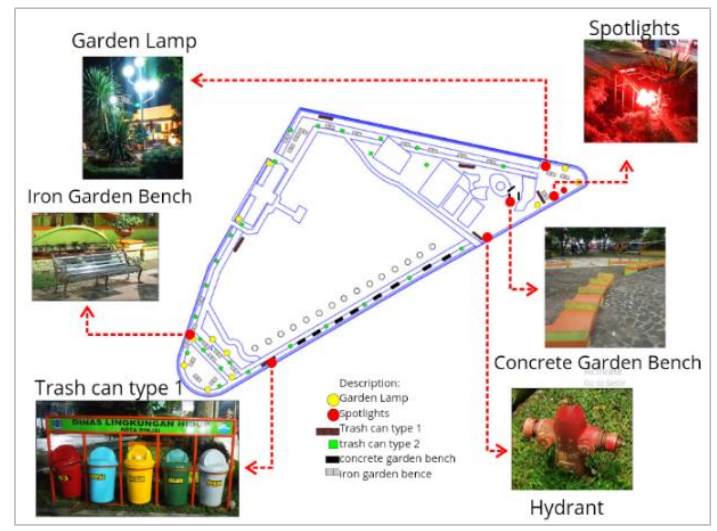

Fig 6. Mapping Complementary Facilities

\subsection{Identification of Non-Physical Aspects of the Area}

There are two practically identified actors in this area, the first actor is a service and goods trader, namely the community that uses the area as a place of work to earn income. While the second actor is the visitor community who enjoys all the facilities of the area according to their orientation, both individually and in groups. The first actor tends to have a constant movement from time to time following the power relations they have in selling goods and services. While the second actor has dynamic movements according to the orientation they have. The orientation of the second actor is a social reality activity related to enjoying the existing facilities following the capital (ability) it has.

\subsubsection{Identification of Merdeka Square User Orientation}

Humans (actors) are targets or objects from the spatial pattern to form a pattern of activity later. In the Merdeka Square area, users have a diversity ranging from age to occupation. Visitors to public open spaces usually do not have age criteria and anyone can visit them. The orientation of users on the Merdeka Square public green space is dominantly school children, traders, and general visitors from inside and outside the city. The habitus is a way of internalizing social conditions in the individual, to the extent that they become an integral part of his spontaneous behavior [27]. The results of this observation explain that the Merdeka Square in Binjai City is dominated by teenagers because the available facilities are more oriented to their activities. Even so, children and parents can be able to enjoy the area because there is a second actor who peddles goods and services with affordable value as a complement to enjoying the area.

\subsubsection{Identification of Freedom Square Visitor Activity Patterns}

The results of the research on activity patterns that occur when viewed from the average daily visitors who come can be seen in Table 3 . below. The area has the highest peak capacity for the number of visitors on weekends. 
Table 3. Visitors Per Day in Merdeka Square

Day

Monday to Thursday (weekdays / school days)
Information

Visitors on Monday to Thursday, especially in the morning, are usually relatively quiet, there are only a few visitors who do jogging. But not as busy as weekends. During the day it is not too quiet because school children have gone home and are usually seen around Merdeka Square to wait for public transportation to arrive, visitors during the day are not crowded because it is quite hot in the public open space area of Merdeka Square. However, in the afternoon after Asr time, street vendors descended on Merdeka Square and began to prepare their sales, so that in the afternoon and evening it became crowded with visitors but not as busy as holidays (weekends).

Friday is the time of worship for Muslims, the Merdeka Square area in the morning and afternoon is Friday empty of visitors. However, it will be crowded again in the afternoon until the evening because the cool atmosphere is also comfortable to support recreation in that place.

Visitors who come on Saturdays have increased, because some workers have had the weekend off. In the morning many visitors come to do jogging. During the day it is not too quiet and crowded in the afternoon as well as at night. On Saturday nights it will be busier than other days.

Visitors who arrive on Sundays are very crowded because it is a weekend holiday. In the morning many visitors come for jogging and car free day. During the day it is not too crowded because it is hot enough to carry out activities at the Merdeka Square public green open space. However, in the after-

Sunday noon and evening there is an increase in visitors who come from within and outside the city for recreation with family and friends. Sunday is the busiest time because various groups of people come to the Merdeka Square area to enjoy the local tourism.

After grouping social activities in regional locations, the flow of visitor activities based on the time of the morning, afternoon, and evening can be seen in the information below:

\section{Morning Activity Movement Flow}

The flow of visitors' movement in the morning can be seen in Figure 7. seen at the marked points, the social activities that occur are sitting, exercising, selling, and walking. In the morning at 09:00-10:00 WIB, the visitors are quiet, what can be seen is only field cleaning officers and people waiting for public transportation. The mapping above also shows a picture of the situation in the morning, the movement in the morning the area used is the zone for exercise equipment, pedestrian circulation, also park benches around the Merdeka Square bus stop. The routine activities of the community have dominated the orientation of visitors not to engage in activities in the area. Merdeka Square in Binjai City is a point of social reality where routine activities have been completed.

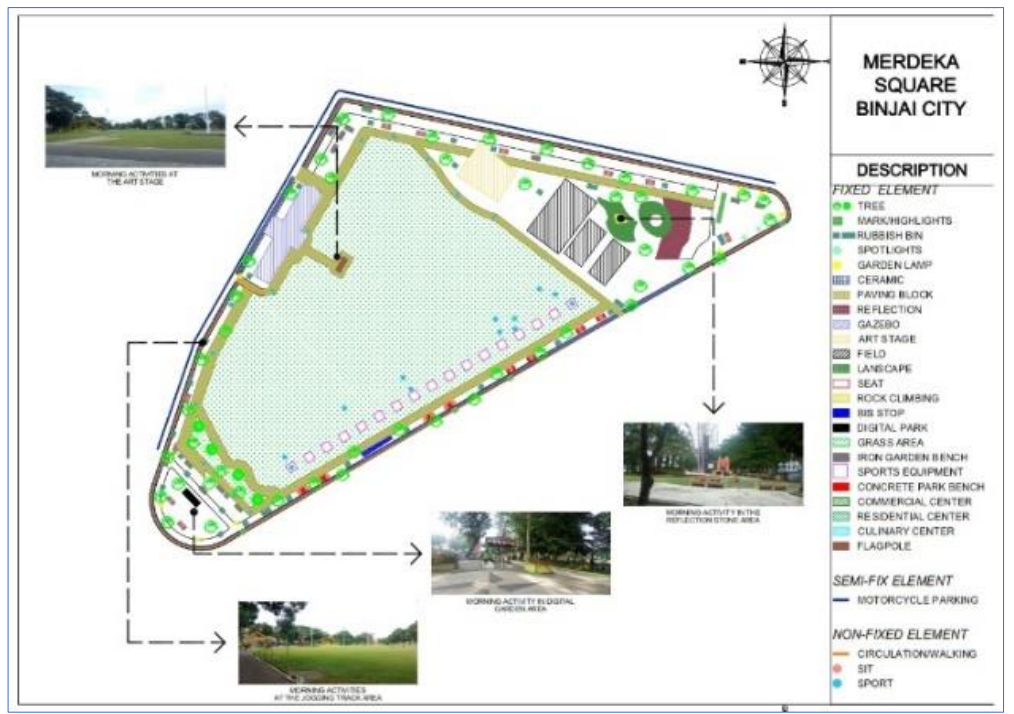

Fig 7. Mapping Morning Activity Movement

\section{Daytime Activity Flow}

The flow of social activist movements that occur during the day at 13:00-14:00 WIB are sitting, walking, selling. In this section, the zone used is pedestrian circulation, benches around the field. Visitors who come do not have a significant number compared to the morning because the hot climatic conditions do not allow to use all the facilities in the area even though some visitors have completed their routines.

The flow of the movement of visitors during the day can be seen in Figure 8. It shows that the point is not too crowded with visitors and the movement of activities is not so prominent. in each Merdeka Square zone. The situation in the mapping image also shows that there are crowded visitors in the afternoon routine and will get busier starting from the afternoon until weekend nights. 


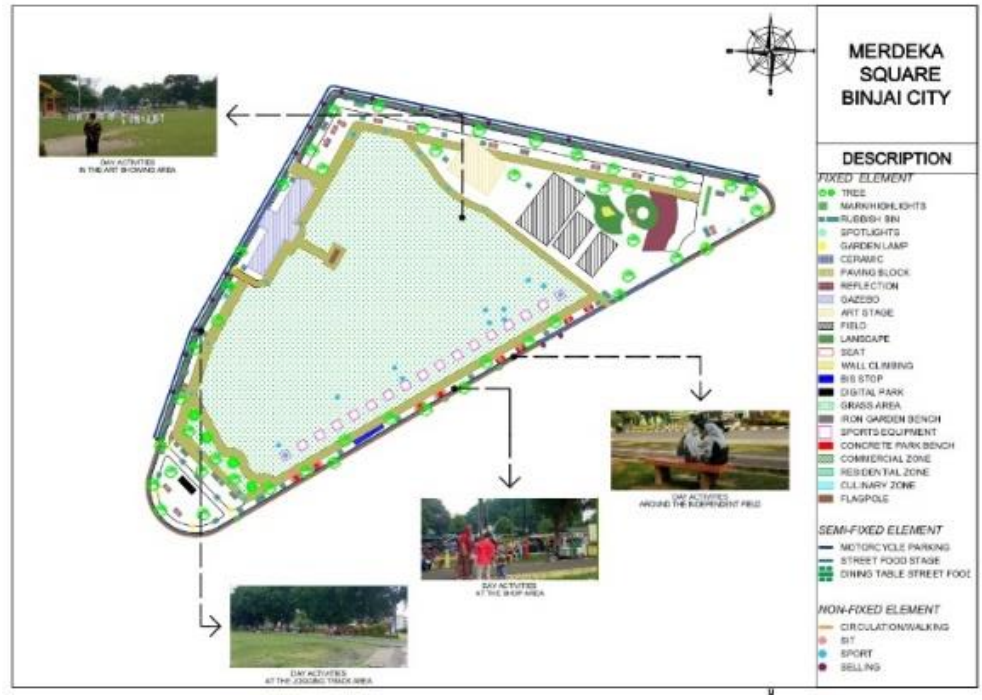

Fig 8. Mapping Daytime Activity Movement

\section{Afternoon Activity Flow}

The flow of activity that occurs in the afternoon at 15:00-17:00 WIB is sitting, walking, selling, playing and also exercising. In this section, the zones used are pedestrian circulation, benches around the field and almost all zones are crowded with visitors except the Binjai Merdeka Park zone, because they are directly faced with red lights and zebra crossings. At this time, some of the research area facilities are used not as visitors on routine days, but as a stop over place to go to their residence after completing their routines. This happens because the location of the area is in the city center, surrounded by office buildings and several school points, making it easier for people to use adequate public transportation services to get to their homes.

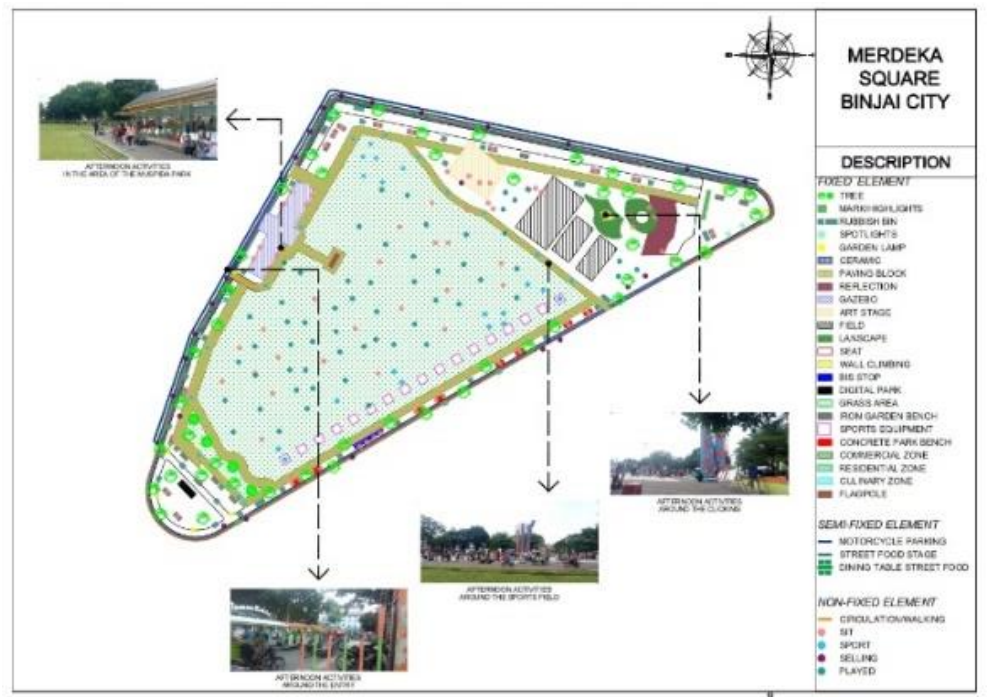

Fig 9. Mapping Afternoon Activity Movement

The flow of the movement of visitors in the afternoon can be seen in Figure 9. It shows the crowded points of visitors and is also full of activity. The situation in the image on the map also shows that there are crowded visitors in the afternoon routine and will get busier on weekend afternoons. Weekends have the same flow of activity in the afternoons but have more and varied capacities. For the first actor, it looks like preparing merchandise and services to welcome the abundant visitors. Meanwhile, the second actor is in a state of preparation at his residence to visit the area at night because he has a longer and more flexible time for teenagers as the dominant visitor community.

\section{Night Activity Movement Flow}

The flow of activity that occurs at night at 19:00-20:00 WIB is sitting, walking, selling, playing and also exercising. In this section, the zones used are pedestrian circulation, park chairs around the field and almost all zones are crowded with visitors. The flow of visitor movements at night can be seen in Figure 10. We can be seen that the movement of activities is very diverse in each Merdeka Square zone. The situation in the image on the mapping also shows that there are crowded conditions of visitors on weeknights and will get busier on weekend nights. 


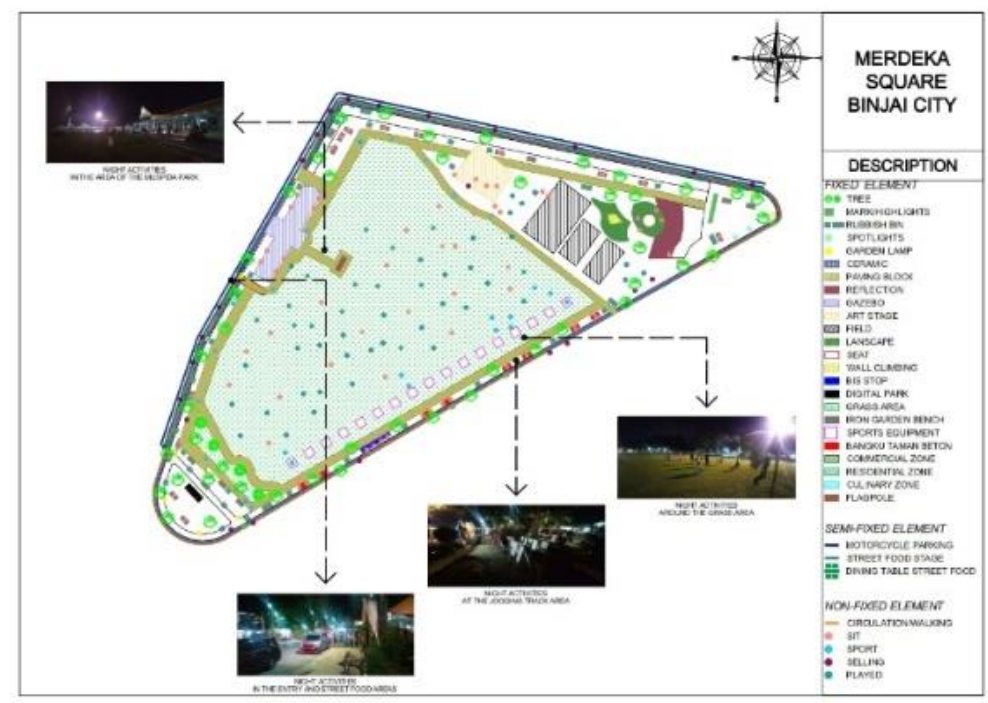

Fig 10. Mapping Night Activity Movement

\subsubsection{Identification of Activity Characteristics and Benefits of Public Green Open Space}

Social activities in public open spaces in the Merdeka Square area consist of gathering to rest, chat, spend time and socialize with the community or family. The benefits of social relations can establish friendship, as a local tourism icon for the people of Binjai City.

Recreational activities at Merdeka Square consist of entertainment, refreshing and sight-seeing around the field, as well as playing and enjoying rental rides such as children's toys and ATV motorbikes. Recreational benefits can entertain yourself and calm the soul.

Economic activities at Merdeka Square consist of selling, renting children's toys and parking attendants. Economic benefits can help parking attendants and small traders make a living. So that it can improve the economic quality of the local community.

Cultural activities at Merdeka Square consist of practicing dance studios on art shows and holding national events. Cultural benefits can preserve the image of the city's local cultural tourism, especially at the Merdeka Square public green open space.

\section{Conclusion}

Based on the analysis that has been carried out on the interaction between Merdeka City Square and the user community as visitors, the life world of the area's identity is a place that has the character to accommodate the social activities of the adolescent community for sports and agility hobbies. The facilities provided in the area indirectly target youth orientation as users for social activities there. So that the places provided do not have clear boundaries, precisely reflecting the mentality of teenagers who tend to be controlled by a sense of freedom towards aspects of the arena, capital, and power.

Therefore, the identity of RTH Merdeka Square in Binjai City is a place as a public space that represents a symbol of youth freedom in fulfilling their social reality. This identity does not represent the visitors of the elderly, adults and children, but serves as a support because the social reality of Merdeka Square which is dominated by teenagers is a habitus activity as an interpretation of social space [28] the cause of the existence of the life-world of Merdeka Square in Binjai City.

\section{References}

[1] S. Ali Rafsanjani, F. E. Rooslan Santosa, and R. Durrotun Nasihien, "Analysis of Planning for Clean Water Needs at Grand Sagara West Surabaya Hotel With the Green Buillding Concept," Int. J. Eng. Sci. Inf. Technol., vol. 1, no. 2, 2021, doi: 10.52088/ijesty.v1i2.55.

[2] M. F. Firmansyah and H. Z. Maulana, "Empirical Study of E-Learning on Financial Literacy and Lifestyle : A Millenial Urban Generations Cased Study,” Int. J. Eng. Sci. Inf. Technol., vol. 1, no. 3, pp. 75-81, 2021.

[3] V. Wineka Nirmala, D. Harjadi, and R. Awaluddin, "Sales Forecasting by Using Exponential Smoothing Method and Trend Method to Optimize Product Sales in PT. Zamrud Bumi Indonesia During the Covid-19 Pandemic," Int. J. Eng. Sci. Inf. Technol., vol. 1, no. 4, 2021, doi: 10.52088/ijesty.v1i4.169.

[4] H. K. Rieka Angkouw, "MEDIA MATRASAIN,” MEDIA MATRASAIN, vol. 9, no. 1, pp. 58-74, 2012.

[5] R. Mirsa, M. Muhammad, F. Fidyati, E. Saputra, and M. Rumiza, "Space Transformation in Residential House Small Entrepreneurs Banana Sale,” Int. J. Eng. Sci. Inf. Technol., vol. 1, no. 4, 2021, doi: 10.52088/ijesty.v1i4.167.

[6] F. Fashri, Piere Bourdieu: Menyingkap Kuasa Simbol. Yogyakarta, Indonesia: Jalasutra, 2014.

[7] R. Mirsa, M. Muhammad, E. Saputra, and I. Farhana, "Space Pattern of Samudera Pasai Sultanate," Int. J. Eng. Sci. Inf. Technol., vol. 1, no. 2, 2021, doi: 10.52088/ijesty.v1i2.120.

[8] D. Hantono, "The Pattern of Public Open Space Activities in the Fatahillah Park Area," J. Compos. Archit., vol. 11 No. 6, 2017.

[9] C. P. Marhendra, L. D. Wulandari, and S. T. Pamungkas, "POLA AKTIVITAS PEMANFAATAN RUANG TERBUKA PUBLIK DI ALUN-ALUN BATU," J. Mhs. Jur. Arsit., vol. 2 No. 2, pp. 1-13, 2014.

[10] M. Muslih, Filsafat Ilmu:Kajian Atas Asumsi Dasar, Paradigma dan Kerangka Teori Ilmu Pengetahuan, I. Yogyakarta: Lesfi, 2016.

[11] A. Sarah, "Identifikasi Pengaruh Karakteristik Ruang Terbuka Publik Terhadap Pola Aktivitas di Kawasan Bantaran Sungai silo." Universitas Muhammadiyah Mataram, Mataram, 2019.

[12] G. Ritzer, Teori Sosiologi Modern, Edisi Ketu. Jakarta, Indonesia: Kencana, 2014.

[13] W. M. Jon Lang, Architectural Theory and Practice and the Behavioral Sciences, First. London: Routledge, 2016.

[14] Christian Norberg-Schulz, Genius Loci. New York: Rizzoli, 1976. 
[15] P. Bourdieu, The Field of Cultural Production, 9th ed. US and UK: Columbia University Press, 1993.

[16] M. Grenfell, Pierre Bourdieu: Key Concepts. North Yorkshire, UK: Acumen Publishing Limited, 2010.

[17] K. Kristianova, "Post-Socialist Transformations of Green Open Space in Large Scale Socialist Housing Estates in Slovakia," Procedia Eng., vol. 161, pp. 1863-1867, 2016, doi: https://doi.org/10.1016/j.proeng.2016.08.715.

[18] A. M. S. Stephen Carr, Mark Francis, Leanne G. Rivlin, Public Space. United State of America: Cambridge University Press, 1992.

[19] R. Hakim, Unsur Perancangan dalam Arsitektur Lansekap [Elements of Design in Landscape Architecture]. Jakarta: Bina Aksara, 1987.

[20] A. Baharuddin, "Kebutuhan Ruang Terbuka Hijau Pada Kawasan Pusat Kota Jayapura," Bumi Lestari J. Environ., vol. 11 (2), pp. 297-305, 2011, doi: https://ojs.unud.ac.id/index.php/blje/article/view/151.

[21] [Act No. 26/2007 on National Spatial Planning], "UU RI No. 26/2007 tentang Penataan Tata Ruang Wilayah Nasional." (accessed Octobr 5, 2021).

[22] Satia, "Sejarah Kota Binjai, Pernah Dijadikan Pelabuhan oleh Bangsa Belanda," Tribun-Medan.com, Mendan, Indonesia, 2021.

[23] G. Adi Putra and D. Triwahyono, "Privatisasi dalam Ruang Publik Studi Kasus : Taman Merbabu Malang," Pawon J. Arsit., vol. 3, no. 01, pp. 69-78, 2019.

[24] R. Shusterman, Bourdieu: A Critical Reader. Massachusetts, USA: Blacwell Publishers Inc, 2000.

[25] M. S. Prof. Dr. Ir. Raihan, Metodologi Penelitian, Pertama. Jakarta, Indonesia: Universitas Islam Jakarta, 2017.

[26] B. A. K. and G. B. Bobby Harreveld, Mike Danaher, Celeste Lawson, Constructing Methodology for Qualitative Research. London: Palgrave Macmillan, 2016.

[27] N. Faucher, The Ontology, Psychology and Axiology of Habits (Habitus) in Medieval Philosophy. Switzerland: Springer, 2018.

[28] Y.-F. Tuan, Space and Place. Minneapolis, London: University of Minnesota Press, 2001. 